\title{
The Use of Analytical Methods in Evaluation of Coptic Wall Paintings Conservation - A Case Study
}

\author{
M. Ali ${ }^{a, *}$ S. Abd El Aal ${ }^{b}$, G. $\mathrm{MAhgoub}^{b}, \mathrm{~A} \mathrm{Sihame}^{c}, \mathrm{~A} \cdot \mathrm{Turos}^{d, e}, \mathrm{~A} \cdot \mathrm{Korman}^{d}$ \\ AND A. STONERT ${ }^{d}$ \\ ${ }^{a}$ Faculty of Archaeology, Conservation Dept., Cairo University, Egypt \\ ${ }^{b}$ Faculty of Archaeology, Conservation Dept., Fayoum University, Egypt \\ ${ }^{c}$ National Research Center, Dokki, Cairo, Egypt \\ ${ }^{d}$ Sołtan Institute of Nuclear Studies, 05-400 Otwock/Świerk, Poland \\ ${ }^{e}$ Institute of Electronic Materials Technology, Wólczyńska 133, 01-919 Warsaw, Poland
}

\begin{abstract}
Egypt has a lot of ancient monasteries and churches, which were decorated with different kinds of wall paintings. Structure of these wall paintings consists of support, plaster and painting layers. Paintings deterioration is primarily due to physicochemical, natural and human factors. The most detrimental factors are bat patches, old varnish and organic waste of birds. All these lead to the gradual disappearance of paintings. Modern technology of conservation is focused on application of new materials for cleaning of wall paintings. Here we report on the use of enzymes, for cleaning surface of coptic wall paintings. Analytical techniques such as particle induced X-ray emission, Fourier transform infrared and optical microscopy were used to evaluate the enzymatic cleaning processes of coptic wall paintings and to identify the chemical composition of red, yellow and white pigments. Particle induced X-ray emission results indicated that there is no change in the chemical composition of the materials and pigments due to enzymatic cleaning. Fourier transform infrared and optical microscopy results confirmed the stability of organic medium before and after treatment of different kind of patches.
\end{abstract}

PACS: 78.70.En, 07.60.Pb

\section{Introduction}

The storerooms of the Coptic museum in Cairo hold many fresco paintings, and some of them are in extremely bad condition. Disfiguration of the surface is due to the application of varnish layer on the surface after the revealing stage; this varnish has caused the darkening of the surface of the painting. Other damage forms are found such as soot layers, dust, wax, micro cracks, and salts.

The aim of this to study is to evaluate the effects of enzymes treatment applied for cleaning of painted surfaces. Particle induced X-ray emission (PIXE) was used to examine and analyze the components of the paintings before and after treatment. Two fresco paintings were selected for this study which involves using enzymes for cleaning. PIXE is one of the most sensitive micro analytical methods [1]. It is non-destructive and is currently used for multi-elemental analysis both in vacuum and in air. The "in vacuum" mode has the advantage of detecting low atomic number elements. The Fourier transform infrared spectroscopy (FTIR) was used to identify the type of varnish and to detect the presence or absence of the paint media. The study cases were also examined under a light microscope and polarizing microscope (PM).

* corresponding author; e-mail: monalyeg@yahoo.com

\section{Objects studied}

The first case study is an incomplete mural painting of several saints (10 individuals) shown in Fig. 1. The size of the painting is $45 \mathrm{~cm} \times 159 \mathrm{~cm}$, and can be found under the catalogue no. 7953. The painting was discovered during the excavation at the monastery of St. Jeremiah

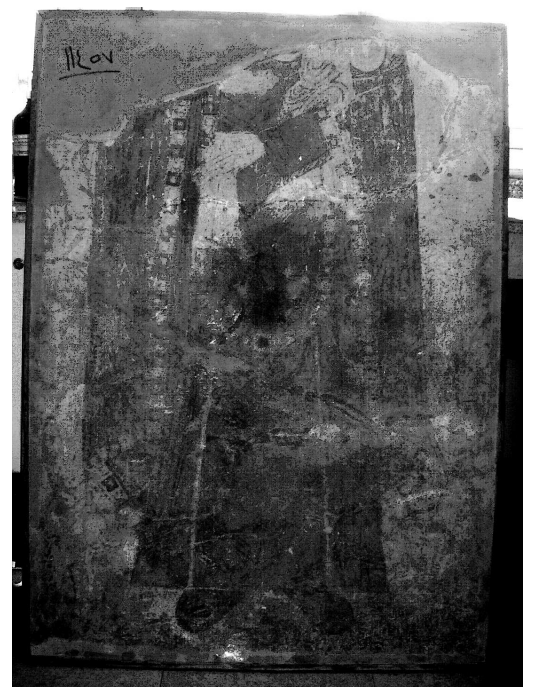

Fig. 2. The second mural painting no. 11457 in Coptic museum. 
in Saqqara. The monastery dates back to the 6th century A.D. and was discovered during James E. Quibell Excavations 1909-1912 [6]. The second mural painting originally decorated the walls of Abdullah Nergi church in Nuba before it was removed and transferred to the storerooms of the Coptic museum. The painting represents Virgin Mary with a size of $89 \mathrm{~cm} \times 123 \mathrm{~cm}$, and can be found under the catalogue no. 11457 and is shown in Fig. 2.

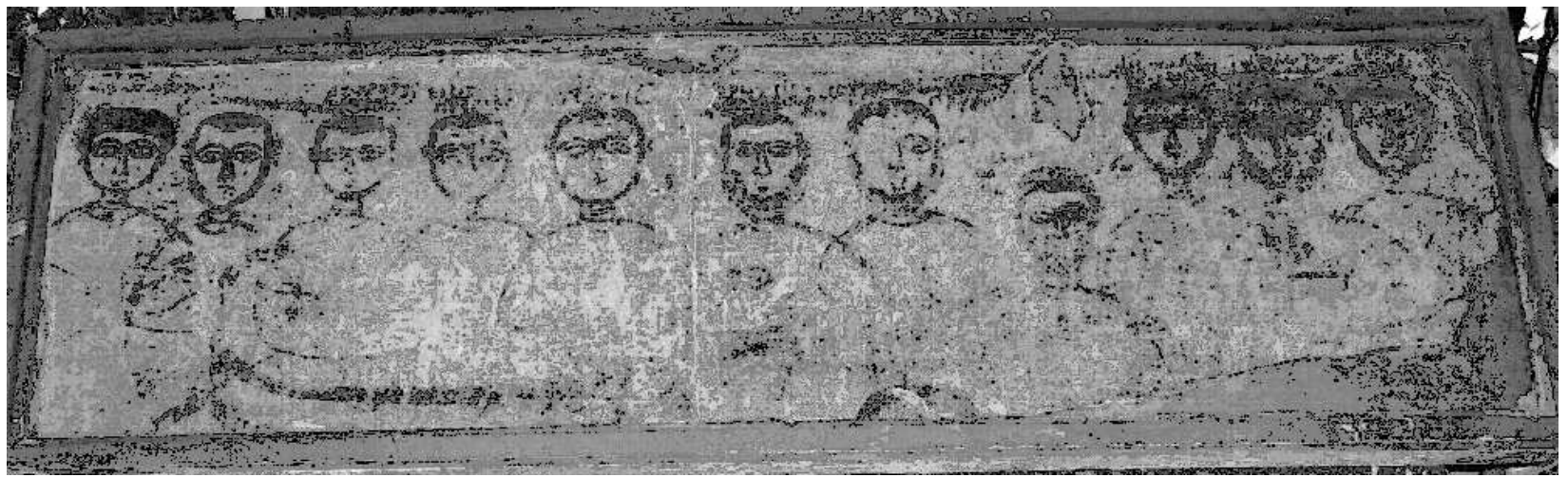

Fig. 1. The first mural painting no. 7953, James E. Quibell excavations - Coptic Museum.

\section{Experimental methods}

\subsection{Investigation and analysis of the case studies}

Samples were collected from areas, which suffer from deterioration and have been subjected to examination and analysis.

1) Ground layer and paint layer samples were analyzed by PIXE before and after cleaning the surface with enzyme.

2) Paint layer and coating layer (varnish) were analyzed by FTIR before and after cleaning the surface with enzyme.

3) Paint layer and coating layer (varnish) samples were examined by light optical microscopy (LOM) and polarizing microscopy (PM).

4) Paint layer and coating layer (varnish) samples were analyzed by FTIR before and after cleaning the surface with enzyme and examined by LOM.

\subsection{Optical microscopy}

Pigments were studied using an Axiotron Zeiss Optical Microscope at the Institute of Electronic Materials Technology (ITME) in Warsaw, Poland and Forschungszentrum Dresden (FZD), Germany under magnification ranging from $3.2 \times$ to $6.5 \times$. Examination of both samples under optical microscope reveals the following:

1. Samples suffer from severe deterioration of its structural coherence. Images show surface damage in the form of soot, dust, salts, and glue and varnish layer used previously during removal of the painting from the monastery of St Jeremiah in Saqqara and its transfer to the Coptic museum in Cairo. All previous overpaintings have covered the paint layer preventing the viewing of the scene.

2. The presence of crystalline salts inside the layer structure of the mural painting has caused the paintings to lose their structural coherence; and consequently the pigments lose their coherence as well.

3. The grains of the red (hematite), and yellow pigments are extremely fine. Average grain size was less than $1 \mu \mathrm{m}$. This is due to very fine structure of hematite mineral as well as to the thorough grinding process (cf. Figs. 3 and 4 ).

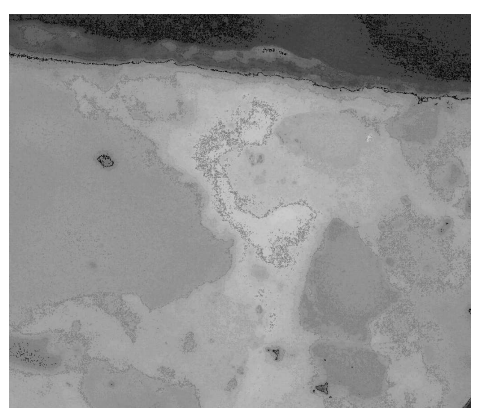

Fig. 3. Photomicrograph of red pigment and varnish layer - first mural painting no. $7953-200 \mu \mathrm{m}$.

\subsection{Polarizing microscopy}

Minute samples from several locations were collected to study the layer structure of the selected mural paintings, the thickness and composition of each layer, the 


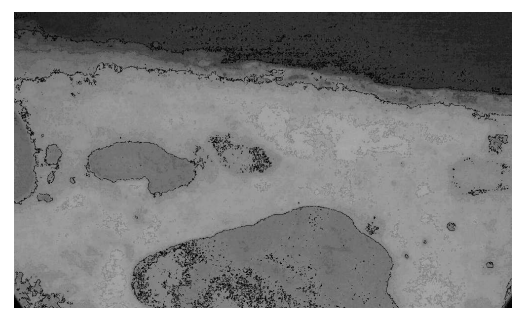

Fig. 4. Photomicrograph of yellow pigment and varnish layer — first mural painting no. $7953-200 \mu \mathrm{m}$.

inner status of both cases, and the preservation state of the paint layer (cf. Figs. 5 and 6). The photomicrograph from first mural painting no. 7953 indicated that red pigment sample is non-homogeneous in thickness, perhaps due to the presence of mistakes during the preparation of the paint layers or presence of over painting layers from varnish. As can be seen in Fig. 5 there are also black spots due to soot.

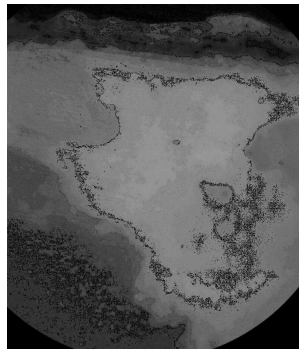

Fig. 5. Photomicrograph of red pigment and varnish layer — second mural painting no. $11457-200 \mu \mathrm{m}$.

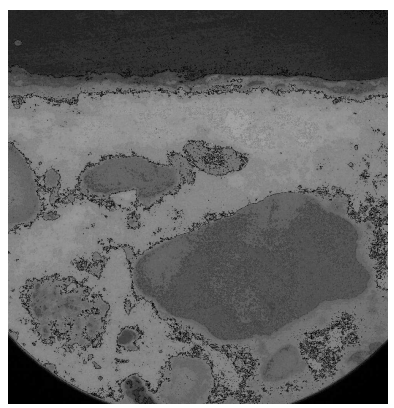

Fig. 6. Photomicrograph of yellow pigment and varnish layer - second mural painting no. 11457 $200 \mu \mathrm{m}$.

In the yellow pigment sample from first mural painting no. 7953 there is a white coating of one painted layer and the color layer is very thin and tends to red confirming the presence of iron. Ground layer is very homogeneous and the grains of mortar layer appear clearly.

Red pigment samples from second mural painting no. 11457 are non-homogeneous in thickness. There is white coating of one painted layer or presence of varnish over painting layers. Figure 6 shows that there are also black spots due to soot.

In the yellow pigment in sample from second mural painting no. 11457 the color layer is very thin; there is one painted layer of white coating. As shown in Fig. 6, ground layer is very homogeneous and the grains of mortar layer appear clearly.

\subsection{PIXE analysis}

Results obtained from PIXE analysis of the samples from the first mural painting catalogue no. 7953 are shown in Figs. 7 and 8 and from the second mural painting catalogue no. 11457 in Figs. 9, 10. They have revealed the presence in the paint layers of the following elements: Si, S, Ca, Ti, Fe, and Zn. The ground layer was found to consist of $\mathrm{Si}, \mathrm{S}, \mathrm{Cl}, \mathrm{Ca}, \mathrm{Ti}$, and Fe. The main element that forms the red pigment is Fe and other elements such as $\mathrm{Ti}, \mathrm{Mn}$, and $\mathrm{Zn}$ have been added to reach a specific red hue $[3,4]$.

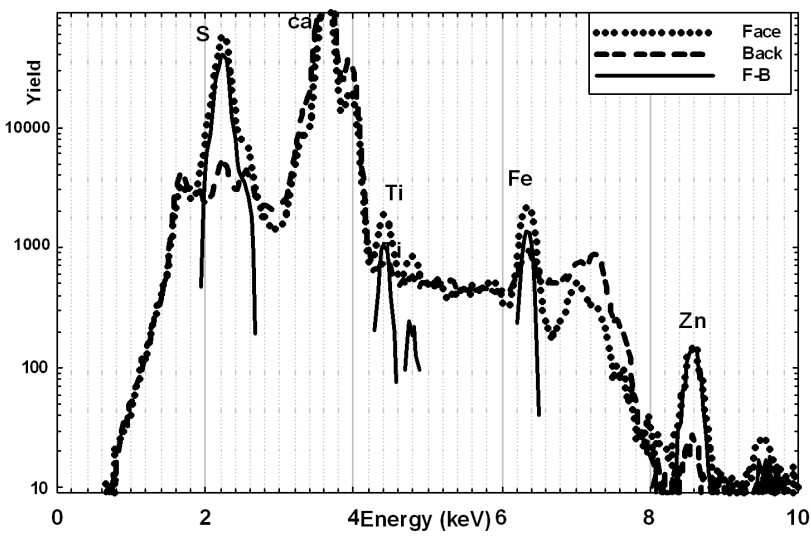

Fig. 7. PIXE spectra of yellow pigment - first mural painting no. 7953.

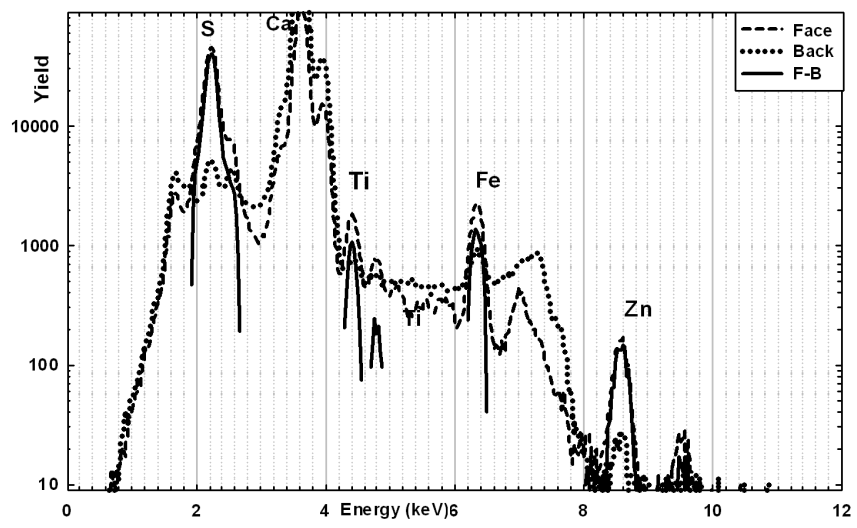

Fig. 8. PIXE spectra of red pigment - first mural painting no. 7953.

The results of the PIXE analysis have led to the following conclusions: 


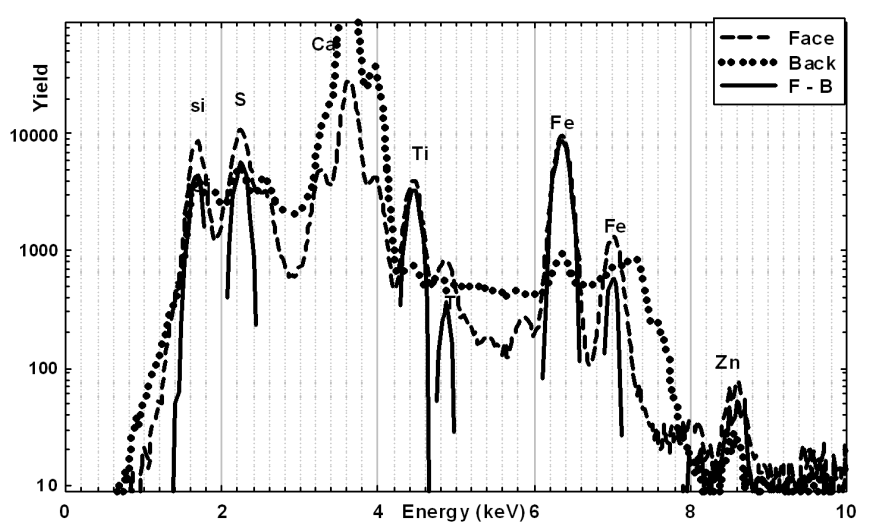

Fig. 9. PIXE spectra of red pigment - second mural painting no. 11457.

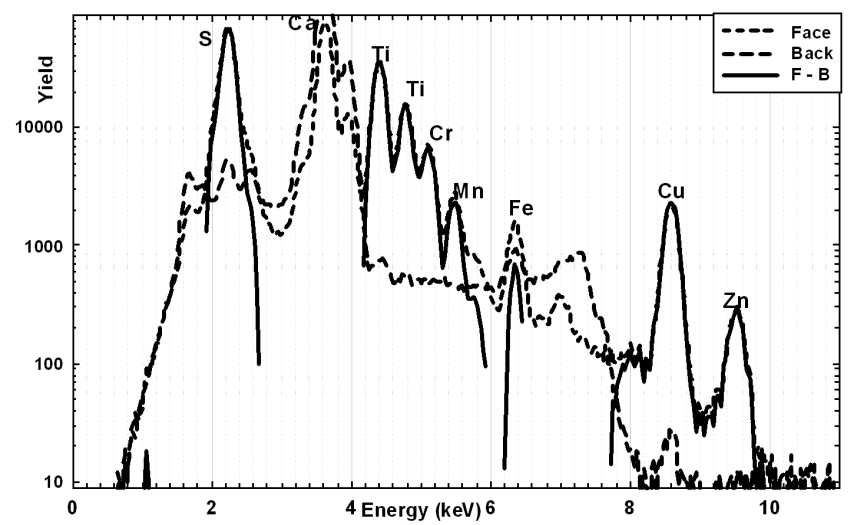

Fig. 10. PIXE spectra of yellow pigment — second mural painting no. 11457.

1. Red paint contains $\mathrm{Fe}$ as a major element, which points to hematite $\mathrm{Fe}_{2} \mathrm{O}_{3}$ as a pigment.

2. Other detected elements found in the paint pigment in some samples are due to some additives used to obtain a darker or lighter red hue. Manganese was added in the form of $\mathrm{MnO}$ to obtain dark yellow color. On the other hand, Ti and $\mathrm{Zn}$ oxides were added to obtain a light red color.

3. Yellow paint contains $\mathrm{Fe}$ that is a strong indication of that the used pigment is goethite $\mathrm{FeO}(\mathrm{OH})$. Other elements were also added to darken or lighten the yellow color.

4. The presence of chlorine $(\mathrm{Cl})$ reveals the contamination with salt $(\mathrm{NaCl})$.

5. Finally the elements detected in ground layers are $\mathrm{Si}, \mathrm{S}, \mathrm{Ca}$, and $\mathrm{Cl}$. This leads to the conclusion that quartz, calcium sulphate (gypsum), and calcium carbonate were used to make the ground layer.

\section{Cleaning study \\ 4.1. Sample preparation}

Selected samples were used to study and evaluate the effect of enzymes on stains, pigments, and organic media so as to select the most effective enzyme for cleaning the chosen cases. They were prepared in similar manner for different types of mural paintings. However, structural buildup, technique, and condition of mural paintings found in tombs, temples, monasteries, and churches (i.e. presence of stains) were considered during sample preparation stage [9].

Fresco samples were prepared in cubes; common stains were applied on the surface to imitate the conditions of archaeological mural paintings. The following stains were added to the surface of the experimental samples:

1. Dust and dirt.

2. Old varnishes which were used as consolidates and are isolating materials.

3. Wax layers which were used as a protective layer in the past.

4. Soot layers which result from the burning of candles and incenses.

\subsection{Enzymes}

Two types of enzymes have been used for cleaning the surface of the experimental samples laboratory prepared enzymes from bacteria and commercial enzymes [5-8]. They are listed in Table I.

\subsection{Application of selected enzymes to real paintings}

The surface of mural painting contains often several disfiguring overlapping stains as shown in cross-section and front view optical microscope images. In order to eliminate them, the use of an accurate and balanced enzyme cleaning technique is required. Results of the experimental study and enzyme activity measurements suggested that the protease enzyme produced by B.5c bacteria provides the best results. The cleaning process was carried out at noon at the optimum temperature for the enzyme action, which is $37^{\circ} \mathrm{C}$. Basing on results of the enzyme activity measurement of B.5c bacteria $10.75 \mathrm{U} /$ flask were used. The enzyme was evenly spread on the stain area of mural painting using a soft, flexible brush (Tables II and III). The cultural filtrate was left on the stain for a period of 10-15 min to partially dissolve the overlapping stains on varnish and animal glue [10].

\section{FTIR analysis}

FTIR technique is applied to determine the functional groups present in the samples [11]. The result of the studied samples before and after treatment with enzyme showed that animal glue was used as varnish layer. The spectra obtained for studied samples were compared with those of animal glue standards. 


\section{Conclusions}

Mural painting no. 7953 stored in the Coptic Museum, which was originally registered as from unknown location, has been assigned by our study to the fifth or sixth century AD and can be attributed to the monastery of St. Jeremiah at Saqqara. It was excavated by Quibble in 1907. After the completion of the clean-up operations with enzymes for first Coptic mural painting some Coptic letters become visible. They can be attributed to the names of twelve apostles.

Examination by optical microscopy revealed that all samples have suffered significant deterioration. Their surface is covered by layers of soot, dust and salt prevent- ing the visibility of colors. Moreover, they were covered by layers of old glue and varnish used to protect them during removal and transportation from the monastery of St. Jeremiah at Saqqara to the Coptic Museum in Cairo.

PIXE analysis of the two Coptic wall paintings indicated that the red color contains Fe as a major element, which points to the hematite as a pigment. Other detected elements found in the paint pigment in some samples are due to some additives used to obtain a darker or lighter red hue. Manganese was added in the form of $\mathrm{MnO}$ to obtain dark yellow color. On the other hand, Ti and $\mathrm{Zn}$ oxides were added to obtain a light red hue.

List of laboratory prepared enzymes and commercial enzymes.

TABLE I

\begin{tabular}{l|c|c|c|c|c|c}
\hline \hline $\begin{array}{l}\text { Enzyme } \\
\text { Stain }\end{array}$ & B.Stero & B.Coag & B.Lic & B.14308 & B.5c & B.Soyamilk \\
\hline glue & ++++ & +++ & ++++ & +++++ & ++++++ & ++ \\
varnish & + & + & ++ & +++++ & ++++++ & +++++ \\
oil, fatty & ++++++ & + & ++ & ++ & ++ & +++ \\
gum & +++++ & +++++ & ++ & +++ & ++ & ++++ \\
soot & +++++ & +++++ & +++++ & ++++ & ++++ & +++
\end{tabular}

Effect of laboratory prepared enzymes on the selected stains.

TABLE II

\begin{tabular}{l|c|c|c|c|c|c|c}
\hline \hline \multicolumn{1}{|c|}{ Enzyme } & $\begin{array}{c}\mathrm{P} 1 \\
(\mathrm{P} 5380)\end{array}$ & $\begin{array}{c}\mathrm{P} 2 \\
\text { P6110 })\end{array}$ & $\begin{array}{c}\mathrm{C} 1 \\
(22178)\end{array}$ & $\begin{array}{c}\mathrm{L} 1 \\
(62316)\end{array}$ & $\begin{array}{c}\mathrm{L} 2 \\
(75577)\end{array}$ & $\begin{array}{c}\mathrm{A} 1 \\
(10065)\end{array}$ & $\begin{array}{c}\mathrm{A} 2 \\
(10069)\end{array}$ \\
\hline Stain & & & & & & & \\
\hline glue & +++++ & ++++ & +++ & +++++ & +++++ & ++++ & +++ \\
varnish & ++++ & +++ & ++ & ++++ & +++++ & +++++ & \\
oil, fatty & ++++++ & ++ & - & +++ & +++++ & - & - \\
gum & ++ & +++ & +++ & - & - & + & +++ \\
soot & ++++ & +++ & ++++ & +++++ & +++++ & +++++ &
\end{tabular}

Effect of commercial enzymes on the selected stains.

TABLE III

\begin{tabular}{l|c|c|c|c|c|c|c}
\hline \hline \multicolumn{1}{|c|}{ Enzyme } & $\begin{array}{c}\mathrm{P} 1 \\
\text { (P5380) }\end{array}$ & $\begin{array}{c}\mathrm{P} 2 \\
\text { S6110) }\end{array}$ & $\begin{array}{c}\mathrm{C} 1 \\
(22178)\end{array}$ & $\begin{array}{c}\mathrm{L} 1 \\
(62316)\end{array}$ & $\begin{array}{c}\mathrm{L} 2 \\
(75577)\end{array}$ & $\begin{array}{c}\mathrm{A} 1 \\
(10065)\end{array}$ & $\begin{array}{c}\mathrm{A} 2 \\
(10069)\end{array}$ \\
\hline glue & +++++ & ++++ & +++ & +++++ & +++++ & ++++ & +++ \\
varnish & ++++ & +++ & ++ & ++++ & +++++ & +++++ & \\
oil, fatty & ++++++ & ++ & - & +++ & +++++ & - & - \\
gum & ++ & +++ & +++ & - & - & + & +++ \\
soot & ++++ & +++ & ++++ & +++++ & +++++ & +++++ &
\end{tabular}

It was also found that yellow paint contains Fe, which is a strong indication that the used pigment is goethite
$\mathrm{FeO}(\mathrm{OH})$. Other elements were also added to darken or lighten the yellow color. Moreover, the presence of chlo- 
rine $(\mathrm{Cl})$ reveals the contamination with salt $(\mathrm{NaCl})$. The elements detected in ground layers are $\mathrm{Si}, \mathrm{S}, \mathrm{Ca}$, and $\mathrm{Cl}$. This leads to the conclusion that quartz, calcium sulphate (gypsum), and calcium carbonate were used to make the ground layer [12].

The result of the studied samples by FTIR before and after treatment with enzyme showed that animal glue, which was used as varnish layer, can be removed without any effect on the paint surface.

\section{References}

[1] B. Gonsior, M. Höfert, B. Raith, in: 2nd Int. Conf. on Non-destructive Testing, Microanalytical Methods and Environment Evaluation for Study and Conservation of Works of Art, Perugia (Italy), 1988.

[2] W. Chamot, Handbook of Chemical Microscopy, Wiley, New York 1993.

[3] A. Shaaban, A. Korman, A. Stonert, A. Turos, Vacuum 83, 4 (2009).
[4] A. Shaaban, M. Ali, A. Turos, A. Korman, A. Stonert, J. Nano Res. 8, 71 (2009).

[5] I. Siham, Ph.D. Thesis, Faculty of Science, Cairo University, 1994.

[6] I. Andres, Enzyme Biocatalysts: Principles and Applications, Springer, Dordrecht 2008.

[7] A. Blüher, G. Banik, K. Maurer, E, Thobois, in: Triennial Meeting (11th), Edinburgh, ICOM, Committee for Conservation, Paris, James and James, London 1996, p. 60.

[8] F. Mona, Study and Restoration of Two Mural Painting Fragments, Cairo University, Faculty of Archaeology, Cairo, Egypt 1995.

[9] M. Ali, in: 4th Fayoum Conf. Proc., 2004.

[10] G. Ranalli, J. Appl. Microbiol. 98, 73 (2005).

[11] A. Jurado, J. Anal. Bioanal. Chem. 380, 706 (2004).

[12] M. Uda, Nucl. Instrum. Methods Phys. Res. B 161, 758 (2000). 